\title{
The Effect of Make a Match Learning Models and Cognitive Ability to Recognize the Concept of Number
}

\author{
Siti Rahmatunnisa ${ }^{1}$, Anita Yus ${ }^{2}$, Evi Eviyanti ${ }^{3}$ \\ ${ }_{1,2,3}$ Universitas Negeri Medan, Indonesia \\ srnisa94@yahoo.com
}

Abstract

This study aims to investigate: (1) the difference of ability to recognize the concept of numbers between children taught by Make a Match learning model based on creativity and children taught by Make a Match learning model; (2) the difference of ability to recognize the concept of numbers between children who have high cognitive abilities and low cognitive abilities, and (3) the interaction between Make a Match learning model with children's cognitive abilities on the ability to recognize concepts. The sample in this study is 28 children in class $B 1$ for the experimental class who are taught by Make a Match based on creativity and for the control class, class $B 2$ consisted of 28 children who were taught by Make a Match. They are 5-6 years old children at Raudhatul Athfal Mutiara Bunda Banda Aceh. The results show that: (1) The ability of children who taught by Make a Match learning model based on creativity is 44.96, it is higher than children who taught by Make A Match learning, it is 34.64, (2) The ability to recognize the number concept of children who have high cognitive abilities obtained an average value of $=46.89$, while children who have low cognitive abilities obtained an average value of $=33.21$, and (3) The results show that there was no significant interaction between the use of learning and children's cognitive abilities (high and low) in influencing the ability to recognize the concept of numbers.
Keywords

creativity-based make a match; cognitive ability; concept of number

\section{Introduction}

Education is the most important aspect to enable students to live and behave well, both at the primary and secondary levels of education, especially during childhood education which is called early childhood education or Raudhatul Athfal (RA). It is a form of early childhood education unit in the formal education pathway that organizes general education programs and Islamic religious education for 4 to 6 years old children. This program aims to help develop both psychological and physical potential which includes moral values, religion, discipline, social emotional, independence, cognitive, language, physical, motorist and artistic so that children are ready to enter further education.

In accordance with that, the existence of professional teachers in the field of Early Childhood education is necessary. Educators must be able to provide professional services to their students in order to lay the groundwork towards developing attitudes, knowledge and skills. Hence, students are able to adapt to the environment and prepare themselves to enter basic education. The key to success is determining the success of the implementation of the curriculum and the creativity of the teacher since teacher has an important factor to determine the success or failure of children in learning. Irhamna (2020) statees that 
Mathematics is a universal science. Mathematics is also seen as the queen of science. Cognitive development abilities aim to develop children's thinking skills in order to process their learning acquisition, to find various alternative solutions, to develop mathematical logic skills and knowledge of space and time. Moreover, it improves the ability to sort, classify and prepare for developing thinking skills accurately.

Cognitive abilities can be interpreted as the ability to recognize something (Khadija, 2016: 31); it shows the ability to capture the nature, meaning, or information about something. It refers to child abilities to understand something. Rezeki (2020) states that cognitive style is one of the psychological factors related to learning. Cognitive style is described as stability in personality that affects attitudes, values, and social interactions. Furthermore, according to Patmonodewo cognitive (2008: 27), it is defined as intelligence or thinking. The thinking process is the process of humans acquiring knowledge about the world, which includes the process of thinking, learning, capturing, remembering, and understanding.

Based on preliminary observations at Raudhatul Athfal Mutiara Bunda Banda Aceh, it is found that most children have cognitive abilities that are less familiar with the concept of numbers and number symbols, this is indicated by as many as 19 children or $67.857 \%$ of 28 children have no indicators yet. Children's cognitive abilities in recognizing and understanding the concepts of numbers and number symbols, such as counting 1-10 objects, recognizing the concept of numbers, and recognizing the symbols of numbers 1 10. It can be seen the lack of children's cognitive abilities, many children do not know the sequence of numbers 1-10, besides that the children still have difficulty distinguishing numbers and they are often reversed when write down numbers. Furthermore, when the teacher gives an assignment in the child's worksheet to do something that is the same as the material that has been previously presented, only a small proportion of children immediately respond to the task and are able to do it.

Based on the results of children's worksheets, the results of learning activities for cognitive abilities in recognizing the concept of numbers is low, $49.31 \%$ in the first semester of the 2019/2020 academic year at Raudhatul Athfal Mutiara Bunda Banda Aceh. The children development is still classified as very low. There are 41 children from 84 children or $48.809 \%$ of them are included in the Undeveloped list (BB), this can be seen when implementing learning materials to recognize the concept of numbers. Children are still silent and unable to mention or recognize the numbers shown by the teacher. Then there are 24 children who are included in the list of children starting to develop. It means that in recognizing the symbols of numbers the children are able to recognize the numbers 1-5 and that is still in the process of teacher guidance, and 10 children are included in the list of children developing according to expectations. Children are able to recognize number symbols, and only 5 children who develop very well. They are included in the category of children able to recognize number symbols correctly.

Based on the results of interviews conducted with the teacher at Raudhatul Athfal Mutiara Bunda Banda Aceh, it is found that children have been taught to count numbers 1 10 , but when children count them with objects, there are still those who could not count objects correctly. In addition, some children are not able to count many objects, they are also not able to count by pointing at objects, counting or mention the sequence of numbers $1-10$, pointing to the number symbols 1-10, imitating the symbols of numbers 1-10, and connecting / pairing number symbols with objects 1 to 10 , so that the expected indicators have not been achieved. 
In accordance with the above data, it can also be seen that learning that is carried out tends to be teacher-centered. Learning is dominated by the teacher. Students only listen to what the teacher says without involving students to actively participate in learning. Learning materials are rarely associated with real life situations or children's daily lives. They are asked to count without teaching aids so it is difficult for them. This has a negative impact on the learning process which causes them to be unable to solve the problems. The level of development achievement recognizes the concept of numbers for 56 years old children at Raudhatul Athfal Mutiara Bunda Banda Aceh, it is dominated by undeveloped children at the level of development achievement recognizing the concept of numbers, and namely more than $50 \%$ of children are not able to understand the concept of numbers.

As a matter of fact, efforts are needed to develop children's cognitive abilities in recognizing the concept of numbers through games using learning models that can attract children's attention and interest in learning. By having a game, children have the opportunity to explore, discover, express feelings, become creative, and learn fun. Besides that, it helps children to know themselves, other people and their environment. Therefore, teachers are required to be more creative in making or creating their own media. It is needed in the learning process by utilizing materials in the environment by paying attention to the development of students. Therefore, it triggers to apply game in activities to develop children's cognitive abilities in recognizing the concept of numbers. Many teachers at Raudhatul Athfal rarely use game techniques in learning. This is due to various reasons including cost, long preparation. Interesting games and not many rules are generally fond by children. Teachers can use it to convey learning to children and this can be used in children's cognitive development through the Make a Match learning model or matchmaking games.

Children's learning creativity is very capable of encouraging children to be even more active in learning, especially cognitive abilities in recognizing the concept of number. By performing Make a Match based on children's creativity, it enables to accelerate the process of understanding children in learning, especially in increasing cognitive abilities so that it is easier to understand the concept of numbers. Hence, the authors are interested in applying a learning model that can create children's cognitive abilities and recognize the concept of numbers by applying Make a Match based on children's creativity.

\section{Review of Literatures}

\subsection{The Ability to Recognize Concept of Number}

The concept of numbers in Early Childhood is needed to develop numeracy skills that are indispensable in everyday life, especially the concept of numbers which is also the basis for the development of early childhood abilities and readiness to attend basic education. (Dewi, 2013: 15) According to Ulum (2014: 14) number is a concept of early childhood consisting of names, sequences, symbols and numbers'. To express a number, it can be denoted by a number symbol called a number. In addition, Sudaryanti (2006: 1) states that the concept of numbers is an early childhood concept which is very important for children to master. Meanwhile, according to Ramaini (2012: 4) the concept of number is a set of objects or numbers that can provide a meaning. The conception of numbers is always associated with the work of connecting objects and symbols of numbers. The statement above explains that the concept of numbers needs to be introduced to children 
from an early age, because understanding the concept of numbers will be the basis for mastering the concepts of early childhood later. The concept of number is also a set of objects or numbers that can give a sense.

Based on the above understanding, it can be concluded that the ability to recognize the concept of numbers in early childhood is the child's understanding of connecting the number of objects with the symbol of numbers through numeracy skills so that children think about the meaning of numbers and calculations.

\subsection{Children's Cognitive Abilities}

Cognitive development is the basis for a child's ability to think. Cognitive is a child's thinking process in solving problems with their environment to create a work that is appreciated by their environment and culture. The process of cognition itself includes aspects of perception, memory, thoughts, symbols, reasoning, and problem solving. This is in accordance with the Susanto (2011: 48), it is explained that cognitive is a thought process, namely the ability of individuals to connect, assess, and consider an event. So the cognitive process is related to the level of intelligence which marks a person with various interests, especially aimed at learning ideas.

Based on the various opinions above, it can be concluded that cognitive ability is the skill to understand what is happening in the environment as well as the ability to use memory in solving simple problems. Cognitive abilities are not only genetically innate but are actively determined by the individual himself as well as by an active social environment that stimulates the child to optimally improve his abilities.

\subsection{Make a Match Cooperative Learning Model}

Cooperative learning is a form of learning by way of students learning and working in small groups collaboratively whose members consist of 2 to 6 people with a group structure that is homogeneous and positive interdependence between children so quality learning is created. The cooperative learning model in this research is Make a Match. One of the advantages of this technique is that students find partners while learning about a concept or topic, in a fun atmosphere. Rusman (2012: 223) defines that Make a Match learning model is one of the cooperative learning developed by Lena Curran with the technique of finding a partner while learning about the concept in a fun atmosphere. Suyatno (2009: 72) states that Make a Match model is a learning model in which the teacher prepares a card containing questions or problems and prepares an answer card and then students look for the card pairs. One of the conceptual approaches that teach students to understand concepts actively, creatively, effectively, interactive, and fun for students so that concepts are easy to understand and last a long time in students' cognitive structures.

\subsection{Children's Creativity}

Creativity is something that is necessary in life. It can help someone develop their talents to achieve achievements in life. For learning in school, the first term creativity and adapting this stance is that creativity is the ability to get ideas, especially original ones, are inventive and new. Ali and Asrori (2012: 42-43) explain that creativity is a characteristic that is owned by an individual which is characterized by the ability to create something from a combination of pre-existing works, into a new work. It is different from what has been there before and is done through interaction with the environment to face problems, and looking for alternative solutions by divergent thinking. 
Someone who has creativity always thinks broadly in developing his ideas. The potential for creativity can help create works, both in the form of ideas and quality. According to Hamzah \& Nurdin (2011: 154), creativity is often described as the ability to think critically, have many ideas, be able to combine ideas that have never been combined before and the ability to find ideas to solve problems. According to Beetlestone (2011: 2), creativity can help someone explain and describe abstract concepts by involving skills such as curiosity, ability, discovery, exploration, search for certainty and enthusiasm, all of which are very large qualities found in child. Creativity is needed to make it easier for children to understand lessons that are difficult to understand.

\section{Research Method}

\subsection{Research Location and Time}

The research is conducted at Raudhatul Athfal Mutiara Bunda Banda Aceh, taking into account the following reasons: (1) Raudhatul Athfal has never conducted research with the same problem, (2) Raudhatul Athfal can represent the type of formal school at the early childhood level, and (3) There is a problem where the cognitive abilities to recognize the concept of children's numbers and children's learning creativity at Raudhatul Athfal are still low. This research has conducted for two months starting from February 2020 with a frequency of 6 (six) meetings where each for the research class group has 3 meetings, namely the class that is taught using creativity-based Make a Match learning 3 times and the class is taught using learn to make a match 3 meetings. The research time is adjusted to the lesson schedule at the Raudhatul Athfal Mutiara Bunda Banda Aceh School in the form of a teaching and learning process at Raudhatul Athfal Mutiara Bunda Banda Aceh.

\subsection{Types of Research}

The type of research is Quasi Experimental Method with the research design as the basis for the implementation of research. It distinguishes the influence of the Constructive Game Model and the influence of creativity-based learning models on cognitive abilities and to recognize the concept of number atRaudhatul. Athfal Mutiara Bunda Banda Aceh. Determination of the experimental class is carried out by lottery. The class to be given the treatment is selected 2 classes. The treatment is attempted 6 times where each is for the research class group. The research time is adjusted to the lesson schedule at Raudhatul Athfal Mutiara Bunda Banda Aceh in the form of a teaching and learning process at Raudhatul Athfal Mutiara Bunda Banda Aceh, the first pre-test meeting, the second to third meeting the teaching and learning process, the fourth meeting carried out a cognitive ability test and the ability to recognize the concept of children's numbers (post-test).

\subsection{Population and Sample Research}

The population in this study is all children at Raudhatul Athfal Mutiara Bunda Banda Aceh consisting of eighty four (84) children. This is in line with Sugiyono's statement (2010: 143) population is a generalization area consisting of objects and subjects that have quality and certain characteristics determined by the researcher to study and then draw conclusions. Determination of the sample in this case, two classes are taken with the provision that one class became the experimental class using the make a match learning model based on creativity in Class B-1, which amounted to 28 people and one class is taught with the make a match learning model in Class B-2, which amounted to 28 people. 


\subsection{Data Analysis Technique}

The data analysis technique used in this research is descriptive and inferential statistical techniques. Inferential analysis techniques are used to test the research hypothesis using two-way analysis of variance (ANAVA) techniques. Sudjana (2002) explains that before two-way ANOVA is carried out, the analysis requirements are first determined. It is the normality requirements using the Liliefors test, while for the homogeneity requirements test using the Barlet test. After testing the requirements of the analysis, the two-way ANOVA test is then carried out, if it turns out that the results of the research hypothesis state there is an interaction, then further testing is carried out using the Scheffe test if the number of samples for each cell is different or the Tuckey test if the number of samples for each cell is the same.

\section{Results and Discussion}

\subsection{Research Result}

Based on the post-test data, the students' ability to recognize the concept of numbers using Make a Match learning based on creativity and using Make A Match learning at Raudhatul Athfal Mutiara Bunda Banda Aceh can be shown by calculating the average value of the results. The summary results are presented in Table 1 below.

Table 1. Description of Analysis Result of the Ability to Recognize the Concept of Numbers Using Two Path Anava

\begin{tabular}{|c|c|c|c|c|c|}
\hline \multicolumn{6}{|c|}{ Tests of Between-Subjects Effects } \\
\hline $\begin{array}{l}\text { Dependent } \\
\text { Variable: }\end{array}$ & $\begin{array}{l}\text { Concept of } \\
\text { Numbers }\end{array}$ & & & & \\
\hline Source & $\begin{array}{l}\text { Type III Sum } \\
\text { of Squares }\end{array}$ & df & $\begin{array}{l}\text { Mean } \\
\text { Square }\end{array}$ & $\mathrm{F}$ & Sig. \\
\hline $\begin{array}{c}\text { Corrected } \\
\text { Model }\end{array}$ & $4256.172^{\mathrm{a}}$ & 3 & 1418.724 & 40.879 & 0.000 \\
\hline Intercept & 89598.508 & 1 & 89598.508 & 2581.707 & 0.000 \\
\hline Metode & 1633.649 & 1 & 1633.649 & 47.072 & 0.000 \\
\hline Kognitif & 2763.830 & 1 & 2763.830 & 79.637 & 0.000 \\
\hline $\begin{array}{c}\text { Metode } * \\
\text { Kognitif }\end{array}$ & 0.659 & 1 & 0.659 & 0.019 & 0.891 \\
\hline Error & 1804.667 & 52 & 34.705 & & \\
\hline Total & 94783.000 & 56 & & & \\
\hline Corrected Total & 6060.839 & 55 & & & \\
\hline
\end{tabular}

Based on the results of data calculations, it can be seen that children's ability to recognize the concept of numbers taught by using Make A Match learning based on creativity obtained an average value $=44.96$ while children's ability to recognize the concept of numbers taught by Make A Match obtained an average value $=34,64$. The results of the analysis of variance for both studies show that the fh price of 47,072 is greater than the fl price of 3,978 at the significant level $\alpha=0.05$ so that $\mathrm{H} 0$ is rejected and 
$\mathrm{Ha}$ is accepted at the significant level $\alpha=0.05$. Thus, it can be concluded that the hypothesis which states that children who are taught using Make A Match learning based on creativity gain the ability to recognize the concept of numbers higher than children who are taught by learning Make A Match are tested.

Furthermore, it can be seen that children who have high cognitive abilities get an average value $=46.89$, while the ability to recognize the concept of numbers for children who have low cognitive abilities get an average value $=33.21$. The results of the analysis of variance for both learning cognitive abilities shows that the fh price of 79,637 is greater than the fl price of 3,978 at the significant level $\alpha=0.05$ so that $\mathrm{H} 0$ is rejected and $\mathrm{Ha}$ is accepted at the significant level $\alpha=0.05$. Thus, it can be concluded that the hypothesis which states that there is a difference of children's ability to recognize the concept of number who have high cognitive and low cognitive abilities.

Based on the results of the hypothesis testing above, it is obtained th $=0.019$ and the critical value $\mathrm{ft}=3.978$ at the level of $\alpha=0.05$. These results indicate that $\mathrm{fh}=0.019<$ $\mathrm{ft}=3.978$, so it can be concluded that the null hypothesis states that there is no interaction between learning factors (creativity-based Make A Match and Make A Match) and children's cognitive ability factors (high and low) in influencing the ability to recognize the concept of numbers. The significance level of 0.89 , it turns out that this value is greater than $\alpha=0.05$ or P-value $>\alpha$, so it can be concluded that the null hypothesis which states there is no interaction between learning factors (Make A Match based on creativity and Make A Match A Match) with children's cognitive ability factors (high and low) in influencing the ability to recognize number concepts is acceptable. It can be concluded that there is no interaction between learning factors (Make A Match and Make A Match based on creativity) and children's cognitive abilities (high, and low) in influencing the ability to recognize number concepts as shown in Figure 1 below:

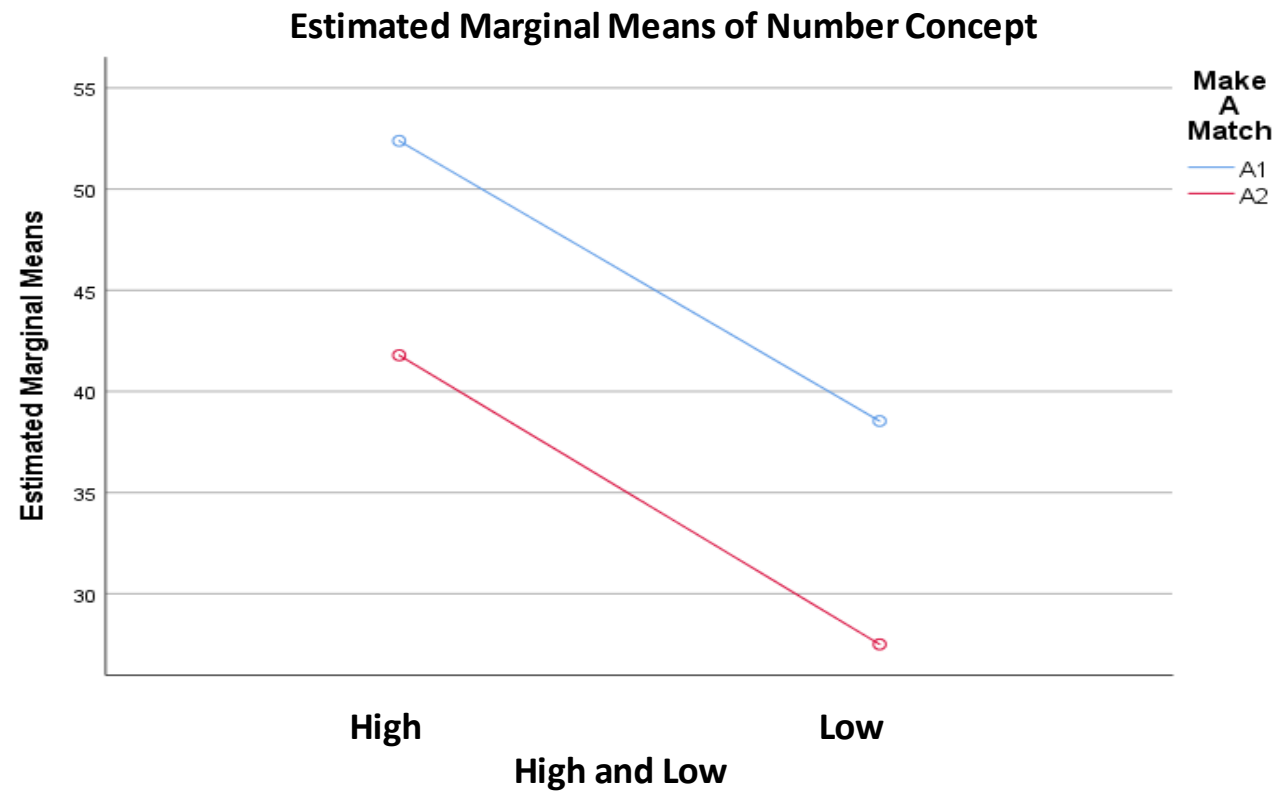

Figure 1. Graph of Learning Interaction (Make a Match Based on Creativity and Make a Match) and Cognitive Ability towards the Ability to Recognize Number Concepts 
Based on Figure 1 above, it can be explained that learning (Make A Match based on creativity and Make A Match) is in accordance with children's cognitive abilities (high and low) in increasing the ability to recognize number concepts. This can be seen from the mean value of each data group that the ability to recognize the concept of numbers taught by learning Make A Match based on creativity, namely the high cognitive ability group (52.38), and the low cognitive ability group (38.53), it is higher when compared to children who are taught with Make A Match learning is the high cognitive ability group (41.79), and the low cognitive ability group (27.50). The results showed that there is no significantly interaction between the use of learning (creativity-based Make A Match and Make A Match) and children's cognitive abilities (high and low) in influencing the ability to recognize number concepts. The difference in the average score of the ability to recognize the concept of numbers and the average score of cognitive abilities (high and low) are taught by learning to make a match based on creativity simultaneously increased significantly. This shows that learning can accommodate the level of ability to recognize the concept of numbers. It is creativity-based Make a Match learning can accommodate children's cognitive abilities both high and low. Based on the results of the research analysis, it is known that the cognitive abilities of children both high and low increase when taught by learning Make a Match based on creativity.

The picture above also identifies that the ability to recognize the concept of numbers taught by creativity-based Make a Match learning gets a better benefit compared to children taught with Make A Match learning, both with low and high cognitive abilities. This can be shown by the difference in the mean difference in the ability to recognize the concept of numbers between children taught through creativity-based Make a Match and Make a Match.

\subsection{Discussion}

Based on the above data collection, it can be concluded that the ability to recognize the concept of children using Make a Match learning based on creativity is higher than the ability to recognize the concept of numbers using Make a Match learning. This is in line with Schunk (2012) that constructivism theory is a learning theory that emphasizes children's ability to build their own knowledge so that children tend to understand and analyze the knowledge they have. This means that children who are taught using Make a Match learning based on creativity gain the ability to recognize the concept of numbers is higher than children taught with Make a Match learning. Through Make a Match learning based on creativity, it is hoped that it will stimulate children to think actively, build understanding and ideas to find solutions to problems. The ability to recognize the concept of children's numbers by using Make a Match learning based on creativity can contain knowledge that is easy and can be imagined by children. This is in accordance with the view that says that a teaching material can be taught, among others, if it is related to the initial knowledge possessed by students.

Based on the above discussion, it can be concluded that creativity-based Make A Match learning is better used in the learning process than Make A Match learning in terms of solving problems, as well as in taking ideas that can increase the ability to recognize the concept of numbers. The ability to recognize the concept of numbers by using Make A Match based on creativity will further activate the ability of children's reasoning and thinking abilities so that it allows children to understand more quickly to recognize the ability to recognize number concepts given by the teacher. 
There are children who have high cognitive abilities and low cognitive abilities. It is said that they have high cognitive abilities because their ability to understand recognizes concepts and analyze the material provided is so good in understanding the material given. This means that children are happy, enthusiastic and understand and the lesson can be absorbed properly. So that the cognitive abilities of children who use creativity-based Make A Match learning are higher than the cognitive abilities of children who use Make A Match learning, even though they are both learning (creativity-based Make A Match and Make A Match). By using Make a Match learning based on creativity, it will be easier for children to improve their ability to recognize number concepts.

Teachers who teach in the classroom are expected to be able to direct children's cognitive abilities. In learning process, a teacher's ability to determine the success of the ability to recognize the concept of numbers, the learning applied by the teacher must be varied. By implementing appropriate learning, it allows children with high cognitive abilities to have the ability to recognize the concept of numbers better. According to Skinner (Schunk, 2012), if the child's response is good, it must be immediately given positive reinforcement. The response is even better so that the ability to recognize the concept of number is also good. The increased ability to recognize the concept of numbers can affect enjoyment in learning so that children continue to have cognitive abilities to learn.

The results of hypothesis testing show that the cognitive abilities of children who use creativity-based Make A Match learning are higher than the cognitive abilities of children who used Make A Match learning, even though they both make A Match based on creativity and Make A Match. It can be understood that in learning to use Make A Match learning based on creativity, new material is closely related to the material that the child has previously learned. It is the material for the ability to recognize the concept of numbers. This is in accordance with the Sanjaya (2009: 17), each child has different abilities which can be grouped into children with high or low in capabilities. Children who are high-skilled are usually shown by high cognitive abilities in learning, attention and seriousness in taking lessons, etc. On the other hand, children who are classified as lowability are characterized by a lack of cognitive abilities and lack of seriousness in completing tasks.

The differences that are owned by children require different treatment in grouping children and the treatment of teachers in teaching. Attitudes and appearance of children in the learning process are aspects that affect learning. Based on the explanation above, it is clear that the cognitive abilities of children who use creativity-based Make A Match learning are one of the factors that influence the learning process. This means that children who taught Make A Match learning based on creativity have better cognitive abilities than children taught Make A Match learning.

The analysis results obtained, there are differences in the interaction of learning and cognitive abilities of children in influencing the ability to recognize the concept of numbers. On average, groups of children who have high cognitive abilities and are taught using Make A Match learning based on creativity have the ability to recognize the concept of numbers that is higher than using Make A Match learning. Then, on average, the ability to recognize the number concept of the group of children who have low cognitive abilities and are taught using Make A Match learning based on creativity is lower than the group of children who have low cognitive abilities but are taught by using Make A Match learning. So in this case the children's learning and cognitive abilities are significant enough to affect the ability to recognize the concept of numbers at Raudhatul Athfal Mutiara Bunda Banda Aceh. 
The experience that students get in learning activities is the result of student activities while participating in learning. There are many factors that influence learning outcomes, namely internal and external factors. In this study the internal factor is cognitive abilities namely learning outcomes, pretest and posttest and emotional in the form of student learning activities. While the external factor studied is the use of learning models by teachers. Learning models are one of the important factors to achieve success in the learning process because the innovative learning model can activate students in learning. The learning atmosphere will feel more alive. One of them is cooperative learning model. Rusman (2014: 202) which defines that cooperative learning makes a Match based on creativity is a form of learning in the way students learn. Based on the above explanation, the ability to recognize the concept of numbers as a whole, an increase in children's ability before treatment and after treatment, especially in the creativity-based make a Match learning treatment. Whereas in the Make a Match learning class, although there is an increase in the ability to recognize the concept of numbers, the average increase in the ability to recognize the concept of numbers is lower than the average value that have been implemented using learning in Make a Match learning based on creativity.

\section{Conclusion}

Based on the results of the research and discussion previously stated, several conclusions can be drawn, namely, the ability to recognize the number concept of children who get creativity-based Make A Match learning is 44.96 higher than children who get Make A Match learning of 34.64. The ability to recognize number concepts using Make A Match learning based on creativity is higher than using Make A Match learning. Through Make a Match learning based on creativity, it is hoped that it will stimulate children to think actively, build understanding and ideas to find solutions to problems.

The cognitive abilities of children who get creativity-based Make A Match learning are higher than children who get Make A Match learning. It can be seen that the ability to recognize the number concept of children taught by using high cognitive abilities has an average value of $=46.89$, while the ability to recognize the concept of numbers for children who use low cognitive abilities has an average value of $=33.21$. So it can be concluded that the cognitive abilities of children who taught by Make A Match learning based on creativity are higher than the cognitive abilities of children who taught by Make A Match learning. It can be understood that in learning to use Make A Match learning based on creativity, new material is closely related to the material that the child has previously learned, which is the material for the ability to recognize the concept of numbers.

The results show that there was no significant interaction between the use of learning and children's cognitive abilities (high, and low) in influencing the ability to recognize number concepts. This can be seen from the average value of each group of data that the ability to recognize children's number concepts taught by learning Make A Creativity-based matches, namely the high cognitive ability group (52.38), and the low cognitive ability group (38.53), are higher than children taught by Make A Match learning, namely the high cognitive ability group (41.79), and the low cognitive ability group (27.50). 


\section{References}

Ahmad, Mansoor. 2011. Research Methods and Techniques for Writing Scientific Paper Reports. Bandung: PAAP FEB-UNPAD.

Ali, Mohammad. and Mohammad Asrori. 2012. Youth Psychology Student Development. Jakarta: PT. Bumi Aksara.

Beetlestone F. 2011. Creative Learning: Learning Strategies to Boost Student Creativity. Bandung: Nusa Media.

Dewi, VNL. 2013. Care for Neonates Infants and Children under five. Jakarta: Salemba Medika.

Hamzah.B, U, \& Nurdin. 2011. Learning with the PAILKEM Approach. Jakarta: PT Bumi Aksara.

Huda, Miftahul. 2012. Cooperative Learning Methods, Techniques, Structures and Applied Models. Yogyakarta: Student Library.

Irhamna, Amry, Z., and Syahputra, H. (2020). Contribution of Mathematical Anxiety, Learning Motivation and Self-Confidence to Student's Mathematical Problem Solving. Budapest International Research and Critics in Linguistics and Education (BirLE) Journal Vol 3 (4): 1759-1772.

Kurniasih, Imas and Sani, Berlin. 2016. Variety of Learning Model Development for Increasing Teacher Professionalism. Surabaya: Kata Pena.

Masganti, Sit. 2010. Development of Students. Medan: Perdana Publishing.

Munandar, Utami. 2002. Creativity and Talent Strategies to Realize Creative Potentials and Talents. Jakarta: PT Gramedia Pustaka Utama.

Patmonodewo, 2008. Preschool Children Education. Jakarta: Rineka Cipta.

Ramaini, 2012. Increasing the Ability to Recognize the Concept of Numbers through Smart Tube Games at TK Negri Lubuk Basung , 1 (1), p. 4.

Rezeki, R., Sitompul, H., and Situmorang, J. (2020). The Effect of Learning Strategies and Cognitive Styles on Learning Outcomes of Mathematics after Controlling Intelligence. Budapest International Research and Critics in Linguistics and Education (BirLE) Journal Vol 3 (2): 1151-1163.

Rusman. 2012. Learning Models. Jakarta: Raja Grafindo Persada.

Rusman. 2014. Learning Models (Developing Teacher Professionalism). Jakarta: Raja Grafindo Persada.

Sanjaya, Vienna. 2009. Learning Strategies. Jakarta: Golden.

Scunk, Dale H. 2012. Learning Theories (learning theories: educational perspectives). Yogyakarta: Student Library.

Solso, Maclin, Maclin. 2007. Cognitive Psychology. eighth edition. Jakarta: Erlangga.

Sudaryanti. 2006. Introduction to Early Childhood Mathematics. Yogyakarta: Yogyakarta State University.

Sudjana. 2002. Statistical Methods. Bandung: Tarsito.

Sugiono, 2010. Quantitative Research Methods, Qualitative, and $R \&$ D. Bandung: Alfabeta.

Susanto, Ahmad. 2011. Early Childhood Development. Jakarta: kencana Prenada Media Group.

Suyatno. 2009. Exploring Innovative Learning. Sidoarjo: Masmedia Buana Pusaka.

Ulum Ihyaul, et al, 2014. Construction of Performance Measurement Models and Intellectual Capital Disclosure Frameworks. JAMAL Multiparadigm Accounting Journal. Vol. 5 No. 3.pp 345-510. 